\title{
APPLICATIONS OF ALUMINIUM ALLOYS IN CIVIL ENGINEERING
}

\author{
Tihomir Dokšanović, Ivica Džeba, Damir Markulak
}

Subject review

Although aluminium is a long known structural material, its use is not in accordance with the benefits achieved by its implementation. There are several reasons for such an adverse state. Those that stand out are the late development of a regulative framework for the design of structures, and still the need for improvement, lack of knowledge on application examples and not stressed enough potential areas of use. However, positive trends are present and aluminium alloys are competitive, especially if their positive properties can be utilized and negative properties diminished through purpose oriented design approach. Given examples present good application utilization of aluminium alloys characteristics, and shown new application research can provide directions for further expansion of competitiveness. Structural uses are grouped in suitable areas of application and put into local and global context.

Keywords: bridge; façade; refurbishment; roof system; seismic

\section{Primjene aluminijskih legura u građevinarstvu}

Pregledni članak

Iako je aluminij već dugo prisutan konstrukcijski materijal, uporaba mu nije u skladu s dobrobitima koji se ostvaruju njegovom primjenom. Nekoliko je uzročnika takvog stanja. Ističu se relativno kasni razvoj normativnog okvira za dimenzioniranje konstrukcija, i još uvijek potreba za poboljšanjem, nedovoljna raširenost saznanja o primjenama te nedostatno naglašena potencijalna područja primjene. Međutim, pozitivni trendovi su prisutni, a legure aluminija su konkurentne, posebno ako se njegova pozitivna svojstva mogu iskoristiti, a negativna umanjiti kroz proračunski pristup orijentiran prema namjeni. Prikazani primjeri predstavljaju dobro iskorištavanje karakteristika aluminijskih legura kroz namjenu, a nova istraživanja primjena mogu pružiti oslonac za daljnje proširenje konkurentnosti. Konstrukcijske primjene su prikazane kroz moguća područja i stavljene u lokalni i globalni kontekst.

Ključne riječi: fasadni sustav; krovni sustav; most; obnova; seizmika

\section{Introduction}

First significant applications of aluminium alloys in civil engineering emerged in the first half of the $20^{\text {th }}$ century, primarily related to bridge engineering. For instance, the reconstruction of a bridge roadway in Pittsburgh, in 1933[1], and the construction of a railway bridge near New York, in 1946[2]. Such activities enticed the publication of aluminium alloys design manuals, of which Alcoa developed the oldest, around 1930 [1]. Application of design methods developed for steel was not possible for aluminium elements, although aluminium alloys have many similarities with steel. One may conclude that this is the reason why first national editions of manuals for aluminium structural design were established relatively late - the German DIN 4113 in 1958, the English BS CP118 in 1969, the French DTU AL76 in 1976, and the Italian UNI 8634 in 1985.The Aluminum Association (AA) and the European Convention for Constructional Steelwork (ECCS) released the first international manuals Specification for Aluminum Structures and European Recommendations for Aluminium Alloy Structures in 1967 and 1978, respectively.

The established normative background did not offer the same degree of elaboration in design approach as norms for at the time more used materials. Thus, the usage of aluminium for structures did not significantly increase, despite the advantages that aluminium alloys possess. Namely, the combination of a relatively high strength to weight ratio, increased durability and availability in numerous shapes, make aluminium alloys an excellent choice for a wide spectre of civil engineering applications. The reasons for such a late development of aluminium as a construction material, and thus an additional reason for the delay in national technical regulation backup, are [3, 4]: lack of knowledge on its possibilities; relatively complex design procedures; relatively expensive production procedure of primary aluminium; not enough recognition of similar achievements in the world. With the appearance of Eurocodes 1999 [5-9], together with the current edition of Aluminium Specification [10] engineers can take on the problems of design of aluminium structures. The high production price is in the most part a consequence of the electricity needed to implement the Bayer procedure [11]. However, production of aluminium from waste (secondary aluminium) requires 20 times [12] less energy and the melting procedure does not influence its properties [13]. According to the European aluminium association [14] the portion of secondary aluminium in total production is in constant rise, and in Europe in 2011 it was recorded at $48 \%$. The advantages of aluminium are gaining acknowledgment and with it a greater number of reconstructions and new constructions are executed transmission towers, halls, bridges, power lines towers, large span geodetic domes, constructions in extremely low temperatures, etc. [15]. This is partially confirmed by the constant rise of aluminium consumption in the European Union up to 2008, with a new wave of increase in the years that follow - Tab. 1 .

Although it would seem that all obstacles for a more widespread use have been eliminated, a positive trend in increase of structural usage is yet to happen in a large number of countries. This is emphasized where regulations for design are not fully implemented, where there is no engineering practice of aluminium use in structures and where there is no systematic education about aluminium as a possible construction material. Among others, Croatia, the authors' country, can be associated to such conditions. In accordance with these claims, the purpose of this paper is to provide an overview of aluminium alloys application possibilities in civil engineering, to present its advantages, shortcomings, 
and current application expansion research. An additional goal of this paper is to offer a methodical summary of relevant facts related to structural aluminium alloys, in comparison with steel and independently. By providing such information, one can arrive to a more informed decision when evaluating whether aluminium might be competitive enough for a certain application. In addition, new application research can offer direction for possible implementation in practice. Examples of Croatian practice in aluminium alloys implementations can provide backup for further improvement in local context, and more importantly encourage application expansion - they identify current utilization level.

\section{Manufacture of aluminium products and structural alloys}

With today known reserves of bauxite and current level of usage, aluminium can be utilized for another 1000 years [16], and when the possibility of recycling is considered there are almost no limitations in its exploitation. Aluminium's life cycle is similar to that of steel and consists of four stages [13] - (1) mining and production, (2) manufacturing, (3) usage and (4) waste management and recycling - but the production processes through which ingots are converted to various semi products are not the same. As opposed to rolling, when steel is in question, structural elements of aluminium alloys are most commonly formed by extrusion. In fact, extrusion became a significant production procedure with the beginning of use of aluminium. It is a procedure in which ingots, previously heated to a temperature of around $500{ }^{\circ} \mathrm{C}$ [17], are forced through a steel die with a desired shape. Another particularity of aluminium in this context is that the production process yields very small amounts of residual stresses, which can be neglected [18]. Elements made by extrusion can have cross sections in dimensions up to $800 \mathrm{~mm}$ [17], with an unlimited spectre of shapes. It is why production of aluminium products by extrusion is considered lot more versatile than that of steel by rolling. Since new cross section production prices are negligible in comparison to steel, and the time needed to change a production die minimal [17], it is common practice to design sections for specific projects, in order to adopt to various structural and functional demands.

Currently produced aluminium alloys are divided into eight series, dependent on their chemical composition. Structural elements are made from alloys that can be associated to series $5 \times x x, 6 \times x x$ and $7 \times x x$, in which chemical elements of importance are magnesium $(\mathrm{Mg})$, silicon (Si), manganese $(\mathrm{Mn})$ and zinc $(\mathrm{Zn})$. Combinations of given elements provide a balance between strength, corrosion resistance, weldability and extrudability. Additional improvement of properties can be achieved through heat-treating or strain hardening. In accordance, alloys are divided into two groups, heat treatable and non-heat treatable, of which both can be strengthened by strain hardening (cold forming). Alloys that are not heat treatable can be strengthened only by strain hardening. In order to differentiate conditions all alloys are designated with a temper indication ( $\mathrm{T}$ for heat treatable and $\mathrm{H}$ for non-heat treatable). Of the mentioned groups used for structural elements, alloys from the group $5 \mathrm{xxx}$ are non-heat treatable and those from groups $6 \mathrm{xxx}$ and $7 \mathrm{xxx}$ are heat treatable.

Table 1 Aluminium consumption in the European Union, in 1000 tonnes unless stated otherwise [19, 20]

\begin{tabular}{|c|c|c|c|c|c|c|c|}
\hline \multicolumn{2}{|r|}{ USAGE OF ALUMINIUM } & 2005 & 2006 & 2007 & 2008 & 2009 & 2010 \\
\hline+ & Primary Aluminium Production & 3250 & 3056 & 3093 & 3049 & 2180 & 2305 \\
\hline+ & Imports of Ingot & 4674 & 5416 & 5913 & 5320 & 3882 & 5528 \\
\hline+ & Imports of Mill Products & 1095 & 1237 & 1421 & 1445 & 1123 & 1413 \\
\hline+ & Recycling & 4641 & 5037 & 5128 & 4644 & 3684 & 4414 \\
\hline- & Exports of Ingot & 224 & 182 & 161 & 178 & 238 & 202 \\
\hline- & Exports of Mill Products & 1008 & 1024 & 970 & 953 & 773 & 940 \\
\hline \multirow[t]{2}{*}{$=$} & Apparent Aluminium Consumption & 12428,0 & 13536,5 & 14423,8 & 13327,7 & 9858,9 & 12518,1 \\
\hline & Mid-Year Population (Millions) & 488,9 & 490 & 490,3 & 490,6 & 499,7 & 501,1 \\
\hline$=$ & Per Capita Use (kg) & 25,4 & 27,6 & 29,4 & 27,1 & 19,7 & 25,00 \\
\hline
\end{tabular}

Aluminium alloys designation system takes into account all of the stated particularities. Each designation consists of three parts, e.g. EN-AW 3103-H14 or EN-AW 6082-T6. The AW indicates that it is a wrought alloy; the four digits indicate the alloy composition; the last designation part the temper in which the alloy is delivered. Additional information on tempers and chemical compositions can be found in $[1,11]$.

Development of new alloys is a non-stop activity, and although conventional alloys have similar properties in comparison to steel, there are still options for significant improvement. Primarily by using new alloying elements and more unusual production processes, e.g. powder metallurgy [21]. However, there is still a lot of research activity needed for the full exploit of aluminium potential in this regard, as these procedures need to reach industrial level applicability.

\section{Comparison with steel}

Since most engineers are familiar with steel, it is worth mentioning what the most important differences between steel and aluminium are $[17,22,23]$ :

- $\quad$ as opposed to steel, aluminium is not magnetic and does not spark on impact,

- aluminium is not susceptible to corrosion even without any coating,

- due to its lower modulus value, aluminium elements exhibit larger deformations than those of steel, which makes serviceability limit state more significant,

- aluminium is suitable for applications at very low temperatures (it is not prone to brittle failure),

- with the increase of temperature aluminium loses its properties faster than steel - modulus of elasticity is $67000 \mathrm{MPa}$ at $100{ }^{\circ} \mathrm{C}$ and $59000 \mathrm{MPa}$ at $200{ }^{\circ} \mathrm{C}$,

- elements made of aluminium are more prone to fatigue than those made of steel, 
- temperature makes aluminium contract and expand twice as much as steel, but the increase of stress induced by limited displacement is less (lower modulus value),

- if aluminium is connected with other metals (most often steel) there is a possibility of contact corrosion so special attention is needed during the design phase,

- aluminium is more resistant to impulse loads due to its lower modulus value, which means that aluminium alloy structures can absorb more deformation work and dampen oscillations,

- fire insulation materials for aluminium alloys structures need to be efficient in the range from 175 to $350{ }^{\circ} \mathrm{C}$, need to have low density, low heat conductivity and need to be adequately flexible to enable relatively high deformations of aluminium.

Aluminium alloys stress-strain behaviour induces the primary differences in the design process. Aluminium does not have a clearly defined yield point and it exhibits pronounced strain hardening. This combined with a lower modulus value implies that stability issues are more pronounced than with steel. In addition, aluminium profiles have shapes that are more complex and are often non-symmetric due to the possibilities of the extrusion process. Such shapes are hard to generalize in design regulations and there is evident lack of research, as described in [24].

Table 2 Advantages and shortcomings of adhesion joining [25, 26]

\begin{tabular}{|c|c|}
\hline Advantages & Shortcomings \\
\hline $\begin{array}{l}\text { - joining is done without holes } \\
\text { and heat is not introduced; } \\
\text { - distribution of stress and } \\
\text { deformation is uniform; } \\
\text { - concentration of stresses is at } \\
\text { a lower level than with } \\
\text { mechanical joining, which is } \\
\text { especially important in } \\
\text { constructions with cyclic } \\
\text { loading (fatigue conditions) } \\
\text { - this enables a larger } \\
\text { lifespan; } \\
\text { - aluminium alloys can be } \\
\text { joined with other materials; } \\
\text { - adhesion provides more } \\
\text { freedom in connection } \\
\text { design; } \\
\text { - thin and small elements can } \\
\text { be connected; } \\
\text { - connections are gas and } \\
\text { liquid tight; } \\
\text { - the used glue can be } \\
\text { insulators or conductors; } \\
\text { - the glue dampens vibrations; } \\
\text { adhesion lowers the total } \\
\text { mass of the construction. }\end{array}$ & $\begin{array}{l}\text { - forming and design of such } \\
\text { connections is not common } \\
\text { in practice; } \\
\text { - before glue application the } \\
\text { surface in question needs } \\
\text { preparation: } \\
\text { - glue requires time to attain } \\
\text { its final properties } \\
\text { (hardening time) } \\
\text { - adhesion is difficult to } \\
\text { monitor; } \\
\text { - dismantling and repair of } \\
\text { connected elements is } \\
\text { difficult; } \\
\text { - limited behaviour when } \\
\text { exposed to high } \\
\text { temperatures. }\end{array}$ \\
\hline
\end{tabular}

Aluminium elements can be joined mostly similarly as those of steel, by welding, mechanically (bolts and rivets), by adhesion and combinations of these methods. Mechanical connections are similar to those in steel, if contact corrosion is avoided. Adhesion is a more applicable procedure to aluminium alloys than to steel, although it is not widespread in structures, primarily due to lack of design guidelines - a summary of advantages and shortcoming according to Soetens [25] is shown in Tab. 2. Some of the shortcomings are annulated with new technologies, such as laser preparation of adhesion surfaces, which is more described in [26], but there is still research needed in order to make use of such technologies in practice.

Welding of aluminium elements is mostly done by TIG (tungsten inert gas) and MIG (metal inert gas) procedures. These procedures cause significant reduction of mechanical properties, especially for heat-treated alloys, due to temperature annulment of treatment done in the production process. This reduction can attain values of up to $50 \%$ [18]. More on differences in welding steel and aluminium and on the current research trends can be found in [24].

\section{Structural applications}

Although a material's price is often paramount for the choice of its use, comparisons based on price per unit of mass lead to questionable conclusions - due to different strengths, densities and other properties in question. In addition, costs of cutting, handling, transport, erection and maintenance during use should be considered, which are all in favour of aluminium if compared to steel. With these factors considered, aluminium alloy structures can be even more cost effective, although the price of aluminium is about one and a half times [17] higher than that of steel.

Possible price reductions, but also aesthetic gains, are possible due to utilization of one or more of the following properties [27, 28]: low self-weight, resistance to corrosion, cross sections shape functionality, large number of possible surface finishing, reflection of light. Certain unique properties of aluminium like stability of properties in extremely low temperatures, non-magnetism and no spark discharge on impact, make aluminium a high priority choice for various special applications.

In accordance to the given facts, most impactful economic benefits can be attained through the following applications [15, 29, 30]:

- large span roof systems in which variable loads are low in comparison with permanent loads;

- structures located in inaccessible places for which transport and ease of erection are of great importance;

- special structures for which maintenance is hard to carry out;

- $\quad$ structures in aggressive environments;

- $\quad$ structures with movable parts;

- structures that are exposed to extremely low temperatures,

- refurbishment of historic building for which increase of usable load is needed without significant increase of dead loads.

Certain applications of aluminium cannot be assigned to a group such as the listed above. That is the case with the use of aluminium in seismic protection, curtain wall systems or as a part of the sustainability efforts. Namely, Efthymiou [4] gave an overview of some the most popular aluminium systems that contribute to the sustainability of a structure and Panico [31] investigated 
the use aluminium shear panels for seismic protection. Research papers concerning curtain wall systems are scarce, probably due to overlapping of various interested parties and professions.

\subsection{Refurbishment of historic buildings and bridges}

Due to its low weight that guaranties the reduction of permanent loads and enables transfer of greater variable loads, aluminium has proven to be a suitable material for the rehabilitation of historic buildings and bridges. Corrosion resistance is much appreciated for renovations tasks as maintenance interventions are reduced to a minimum.

An example of such application is the restauration of the Italian oldest suspension bridge, Real Ferdinando, built in 1862. As described in [32], project authors followed the positive experience of the restoration projects ideas of similar suspension bridges Groslee, Montmerle and Trevoux in France. The mentioned three bridges, including Real Ferdinando were refurbished by replacing their deck structure with aluminium truss girders (Fig. 1). The deck structure replacement enabled a significant reduction of the bridge self-weight and the required traffic load increase. In the case of Groslee, selfweight dropped from 90 tons to twice less than that [3]. It is also worth mentioning in the context of bridge refurbishment that an aluminium orthotropic plate system for replacing damaged concrete bridge decks was developed and used in Sweden [15].

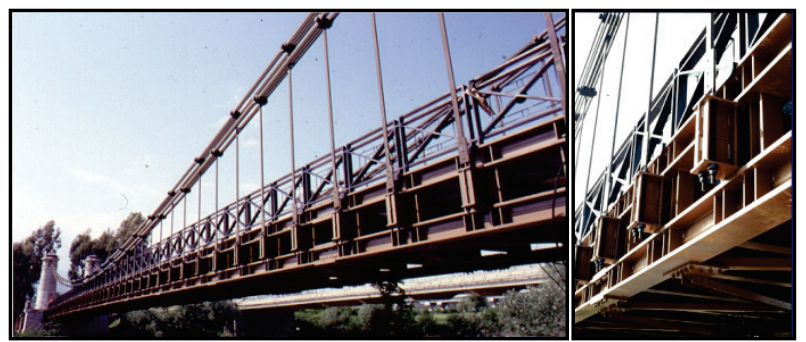

Figure 1 The Real Ferdinando bridge in Italy after re-construction new aluminium deck [32]

Another example is the use of aluminium alloys for the preservation of the ruins and public facilities improvement of an archaeological site Mercati Traianei in Rome (Italy) [33]. Due to aluminium alloys low weight, new structures could be positioned on existing structures, without the need for load capacity improvement. Aside from low weight, aluminium was chosen due to its corrosion resistance and aesthetic properties. In total, two cylindrical vaults, a large grid work roofing and a spherical reticulated dome were constructed - Fig. 2.

\subsection{Seismic protection}

Pure aluminium can be used in passive seismic protection systems due to its low yield strength and high degree of ductility. These properties are favourable for seismic energy dissipation through plastic deformation. The most practical way to utilise given properties is through shear panels (Fig. 3), as they enable control through self-sacrificing. Research conducted by Panico and De Matteis [31, 34] deals with such an application, and it indicates certain positive characteristics in comparison to similar systems made of other materials. It was established that aluminium shear panels delayed early significant damage to frame members and that their collapse mechanisms are favourable. Of the tested full bay and pillar type mechanisms it was observed that better seismic performance is related to pillar type shear wall systems.

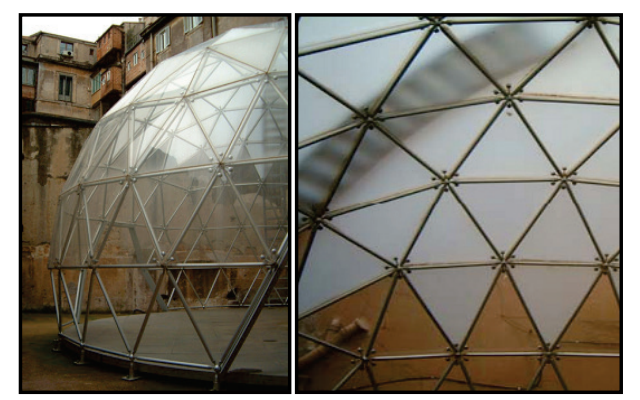

Figure 2 The spherical reticulated dome in the museum of Mercati Traianei in Italy [15]

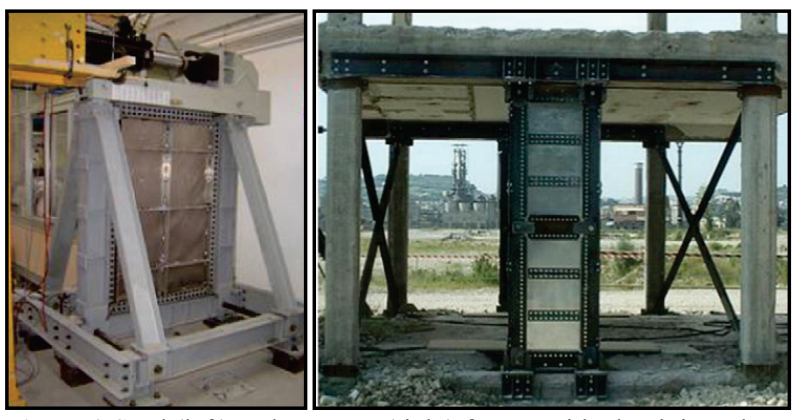

Figure 3 Steel (left) and concrete (right) frames with aluminium shear panels [35]

\subsection{Structures in aggressive environments and inaccessible areas}

Aluminium alloys are a favourable choice when it comes to structures that are situated in remote locations or chemically active environments, and for structures exposed to extreme temperature variations (especially low temperatures). Properties that make aluminium suitable are its low weight, lack of negative implications related to brittleness in low temperatures (as opposed to steel), and low maintenance requirements.

The first example of such an application is a research station located in the area of South Pole (Fig. 4). The aluminium dome is $16 \mathrm{~m}$ high and has a diameter of $50 \mathrm{~m}$. The structure elements had to be transported from the manufacture site, which is over $30000 \mathrm{~km}$ far. Aluminium's low weight was paramount for such a feat, and any economical calculations based on material price were outweighed by transport cost. Also, temperatures in the area vary from -20 to $-80{ }^{\circ} \mathrm{C}$, so avoidance of brittle failure was accomplished by the material selection. The structure weight was 2,4 times less in comparison to a steel variant solution [3].

A special application of aluminium is found in towers for electrical transmission lines and antennas. These objects are often erected in difficult to access areas, to which transport of heavy objects is nearly impossible. In such a case, every possible weight reduction represents significant reductions in costs as helicopters are often used as a means of transport. The increase of shop costs is fully offset by lower erection and maintenance costs. In 
addition, there are situations when electric distribution interruption for maintenance cannot be tolerated - this alone justifies the use of aluminium. Examples can be seen throughout the world and one of them is shown in Fig. 5.

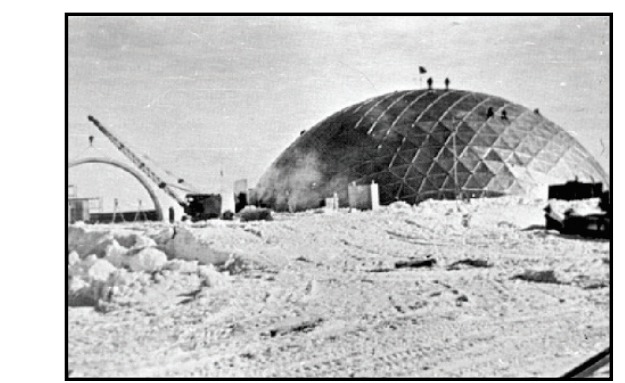

Figure 4 Aluminium dome research station in South Pole [3]

The electrical transmission line shown in Fig. 5 (left) was built in 1956; it is composed of four pillars each weighing 1,7 tonnes, easily transported to any location by helicopter. The mid picture displays an information tower for a football stadium and the right picture a tower for parabolic antennas. Aluminium was chosen because of its lightness and corrosion resistance [15].

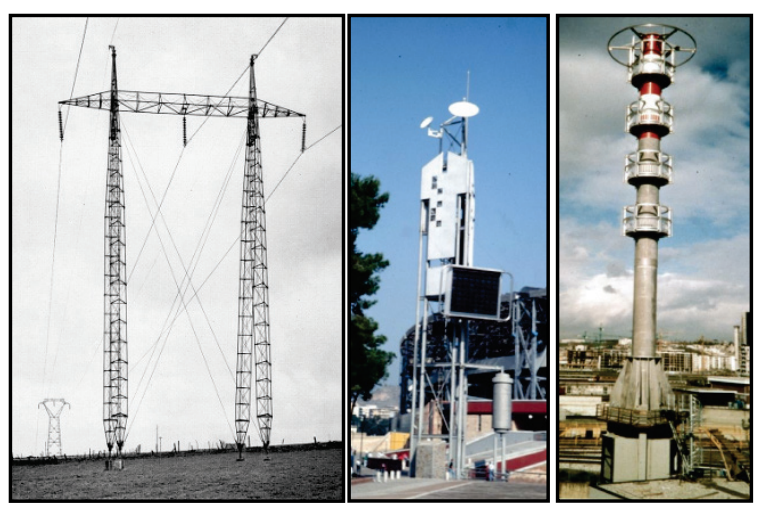

Figure 5 Electrical transmission line tower in France (left) [3] and two antenna towers in Italy (mid and right) [15]

Another good example is the use of aluminium in water/sewage treatment plants. Namely, structures located in the sewage pool, required for waste treatment, are exposed to aggressive influences. The best example is shown in [15], where aluminium was used for the construction of a rotating crane bridge in a settling circular pool - Fig. 6 . These working conditions impose a high level of anti-corrosion resistance which aluminium alloys can fulfil without special treatment. Low construction mass facilitates easier operation and enables energy savings.
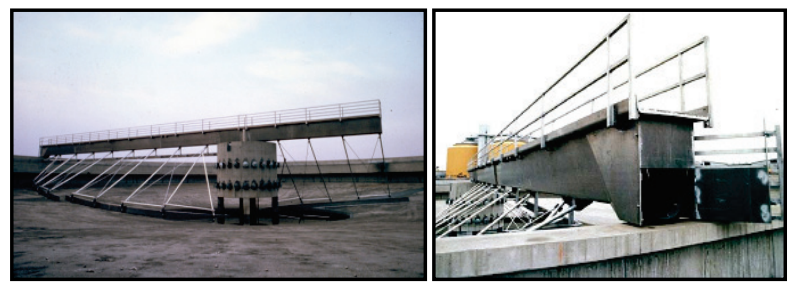

Figure 6 Rotating crane bridge in a sewage treatment plant [15]

Offshore platforms present a special application in which all of aluminium alloys advantages excel. These objects are located in remote areas, exposed to harsh conditions and cross section functionality is of great importance as it can ensure quick assembly and adaptability. Aluminium can be used for stairs, platforms, ladders, bridges and similar easily prefabricated systems that can be transported and readily installed. Helidecks are an already tested solution in such an application as they are in use for more than 40 years [15] - Fig. 7. Aside from modularity and quick erection, aluminium helipads are $70 \%$ lighter than those of steel, and provide with an up to $12 \%$ cost saving [15]. Accommodation modules are also a tested and viable solution in aluminium alloys. An example of such is the Norway accommodation module for the Saga oil field shown in Fig. 8, built in 1990.

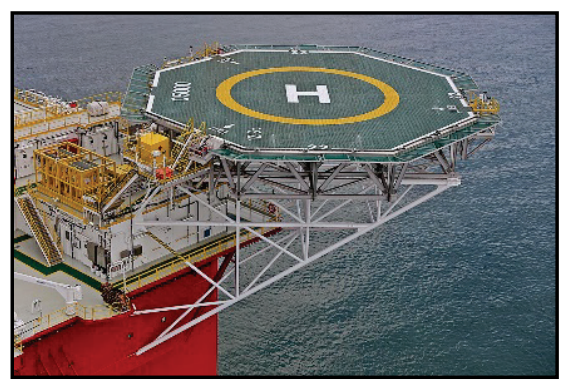

Figure 7 Aluminium helideck on an offshore platform [36]

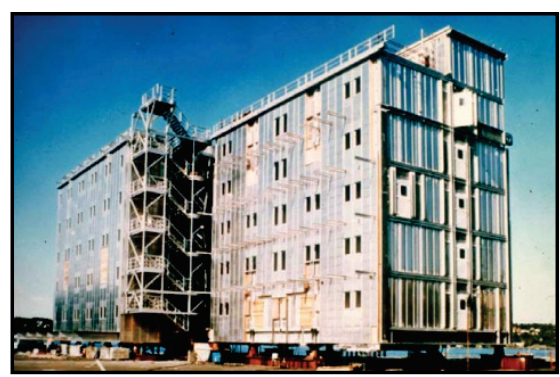

Figure 8 Accommodation module for an oil field before flout-out [17]

\subsection{Bridges}

After the Second World War, several experimental bridges made of aluminium alloys were built in the USA. They were supposed to pave the way for a more widespread application, but the relatively high price of aluminium delayed such efforts. These early experimental structures proved the applicability of aluminium in such use, but also enabled ground for innovation, which showed composite systems aluminium-concrete as a promising direction. Composite sections were advantageous due to a more favourable modulus ratio as opposed to steel-concrete.

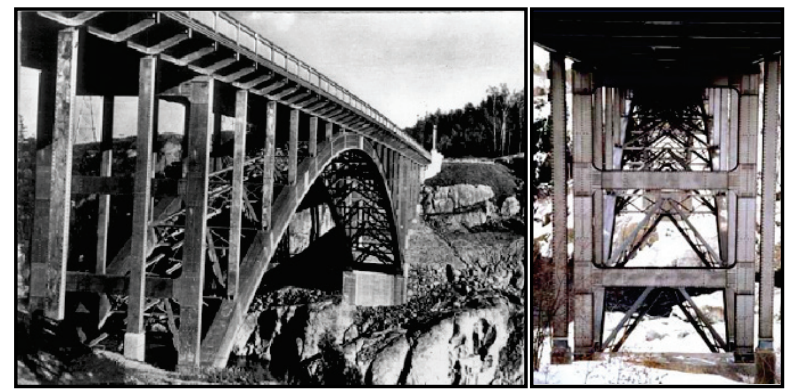

Figure 9 Aluminium arch road bridge in Canada [3]

One of the early successful examples is a road bridge in Canada, which was built in an area with great temperature fluctuations -40 to $+40{ }^{\circ} \mathrm{C}$. It was built in 
1950 and it is the first large span all aluminium bridge, with a span of $153 \mathrm{~m}$ and an arch that spans a distance of $88 \mathrm{~m}$ - Fig. 9. The structure's total weight is $180 \mathrm{t}$, which is about 2,8 times less than the variant steel solution [3].

Another early example, but of a pedestrian bridge, is the Hem-Lenget canal bridge in France, built in 1968 Fig. 10. Its total span is $83 \mathrm{~m}(10+63+10 \mathrm{~m})$, and its total weight is $25 \mathrm{t}$. Aluminium was used because of its corrosion resistance, which ensured durability without any corrosion coating and additional costs during use. Low weight enabled easier handling in the shop and a simple erection process.

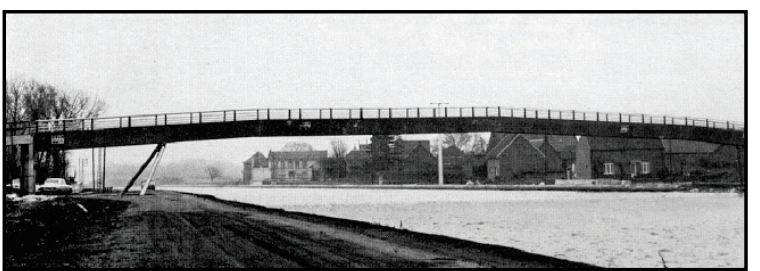

Figure 10 Aluminium pedestrian bridge in France [3]

Modern applications include vehicular, pedestrian and residential area bridges, in Europe, Japan and North America [37]. An example of an aluminium bridge design is described by Soetens and Mennick [38], as they entered an international bridge design contest in The Netherlands. In total five different bridge types were designed for 45 pedestrian and 13 road traffic bridges - Fig. 11. Although the design did not win the contest, it received positive feedback and showed a possibility for a widespread application through modularity.
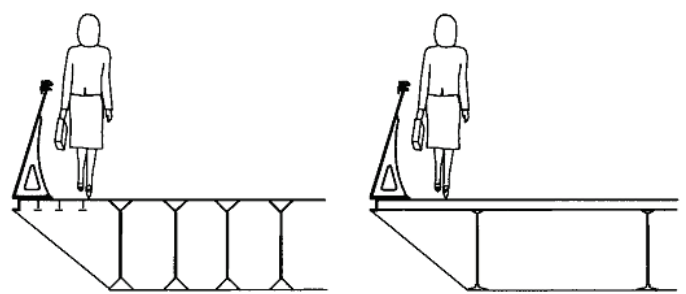

Figure 11 Initial (left) and detailed design for an aluminium alloy bridge [38]

The military has shown a particular interest in aluminium-prefabricated bridges. Due to aluminium low weight, it is possible to quickly and easily assemble elements and reposit them if necessary, which is of great importance when this application is in question. At present it is possible to reach $40 \mathrm{~m}$ of span [15], although there are examples of more challenging spans such as a 56 m span bridge built by the Vickers Defence System, UK [17]. Bridges developed by the Swedish and German army are shown in Fig. 12.

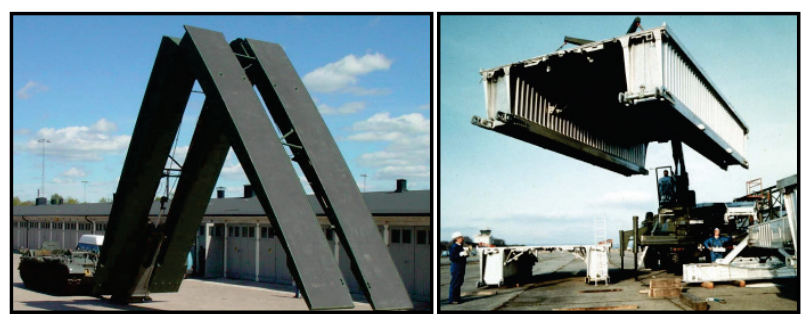

Figure 12 Sweden (left) and German (right) military prefabricated bridges [15]

\subsection{Large span roof systems}

Warehouses, sport halls, storages and certain monumental structures have a roof system made of aluminium alloys. The greatest advantage to be utilized in these systems is the low weight, combined with the absence of maintenance, which is often difficult and expensive with large spans.

The most famous system in this field of application is the reticular space structure. It was utilised on an exhibition centre in Sao Paolo (Brazil) in 1969 - Fig. 13. The structure covered an area of $67600 \mathrm{~m}^{2}$, and only 25 columns with a total height of $14 \mathrm{~m}$ supported it. The truss structure has a height of 2,36 $\mathrm{m}$ and is entirely made of aluminium tube profiles with a weight of $16 \mathrm{~kg} / \mathrm{m}^{2}$. It was bolted in situ, on the ground, and then erected with 25 cranes in only 27 work hours [3].

Another type of structure suitable for roof, large span systems, is a truss frame plane structure. One of the first more famous applications of such type is a warehouse in Atwerpen (Belgium), built in 1958 - Fig. 14. An area of $80 \times 250 \mathrm{~m}$ is covered without columns, spanned by two joint frames made of full columns and trussed beams, placed at intervals of $20 \mathrm{~m}$. The columns are made of steel and everything else of aluminium alloys. The weight of the structure is $120 \mathrm{t}\left(6 \mathrm{~kg} / \mathrm{m}^{2}\right)$, which was seven times less in relation to a variant solution in steel.

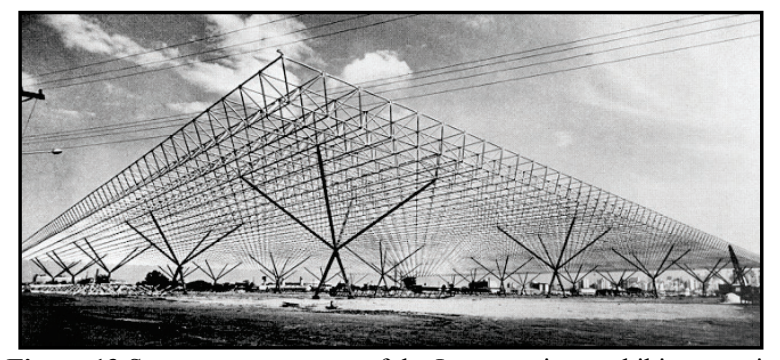

Figure 13 Space truss structure of the Interamerican exhibit centre in Brazil [15]

A structure type that is favourable for large span roof structures, which also utilises aluminium alloys advantages, are domes. One of the more famous structures of this type is the airplane hangar for hydroplanes in Long Beach (USA), built in 1981. This aluminium alloys structure has a diameter of $105 \mathrm{~m}$ and height of $33 \mathrm{~m}$, covered in aluminium panels - Fig. 15.

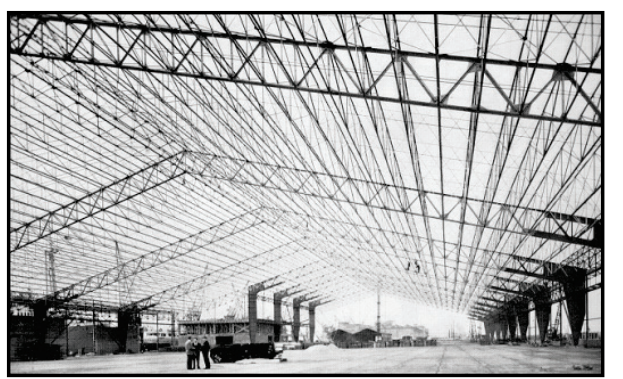

Figure 14 A frame system warehouse structure in Antwerpen [3]

Examples that are more recent relate to industrial applications, for example coal storage. Such an example are the twin aluminium domes in Italy, built in 2009 . Aluminium is popular due to the corrosion resistance that requires no maintenance during exploitation, which 
ensures constant operation. This is often paramount as production halts costs can offset the initial higher cost of aluminium.

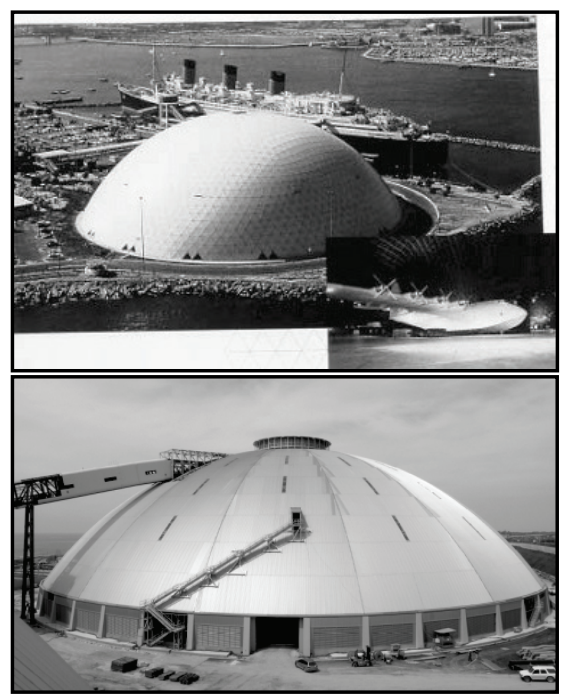

Figure 15 Aluminium dome hydroplane hangar in USA (up) [39] and a coal storage dome in Italy (down) [28]

\subsection{Structural façade systems}

Modern architecture progress has been influenced by metal and glass. One of the earliest window-frame installations was on the University Library at Cambridge in 1936 [17] and now the design of lightweight has become so widespread that it is a standard feature in urban environments. The building envelope executed in aluminium has become a desirable form due to its durability and finish appearance, but also quick assembly made easier with low self-weight and easy maintenance. Typical design practice is to make a suite of special extrusions, often one time project based, which enable assembly by hidden mechanical joints instead of welding. Most often by weaker $6 \mathrm{xxx}$ series that have good surface finish.

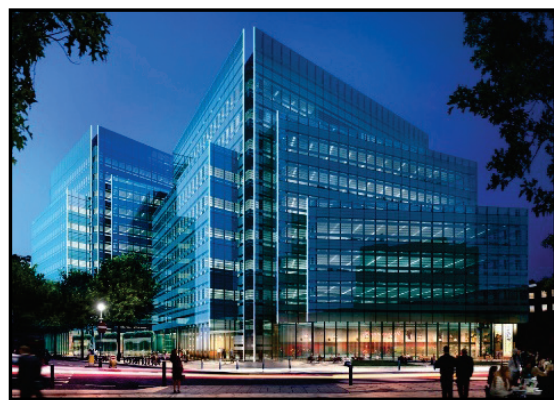

Figure 16 Office and building in London (England) with an aluminium alloy façade system [40]

Examples of such applications are plentiful, whether in the industry, commercial or residential sector. A random newer example is the building Hammersmith Grove shown in Fig. 16, built in 2013 in London (England), which utilises aluminium in its $7000 \mathrm{~m}^{2}$ façade system. Another example is an office building Tanzende Türme completed in 2012, located in Hamburg (Germany), which makes use of double skin and single skin façade systems made of aluminium alloys - Fig. 17 . Additional examples are easily found on the reference pages of major producers of aluminium facade systems, such as the Permastelissa group, Hydro aluminium, Hansen Facades, Sapa, Schüco, Reynaers aluminium, etc.

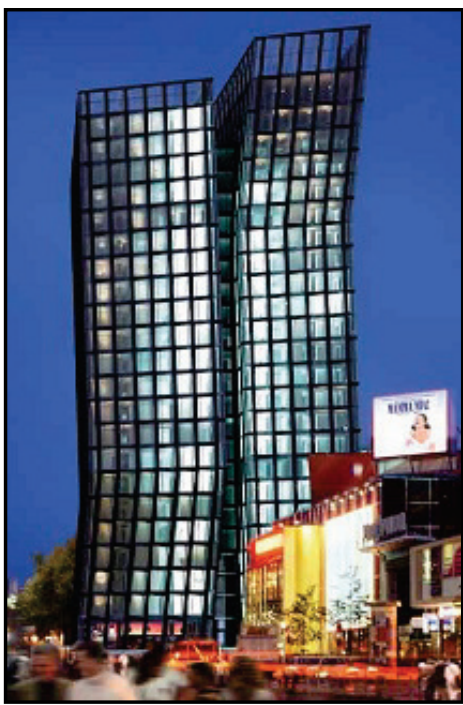

Figure 17 Commercial building in Hamburg (Germany) with an aluminium alloy curtain wall [41]

\subsection{Structural applications in Croatia}

Application examples of aluminium alloys are scarce in Croatia. Reasoning behind this development is the strong tradition of building with reinforced concrete, with minor presence of steel and timber for certain application types. Aluminium is almost solely used for facades, with sparse utilization for special applications such as kiosks and information stands. It can be said that the utilization of aluminium alloys in Croatia is primarily related to architects and designers, not civil engineers.

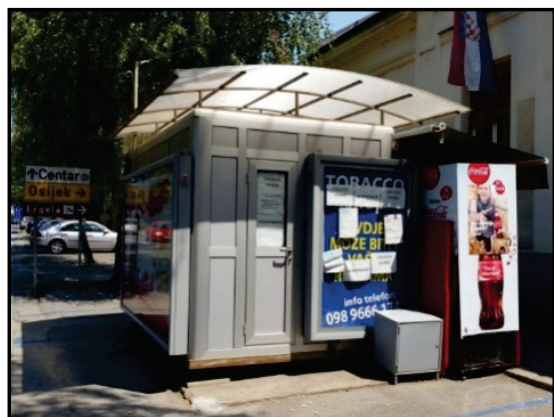

Figure 18 A multipurpose aluminium kiosk in Đakovo (Croatia)

Façade systems executed in aluminium, whether curtain walls or panels, are as mentioned being used due to modern architectural trends which highly value clean surfaces, transparency and slenderness. Kiosks are executed in aluminium due to the mentioned modularity, which is utilized in offshore applications, but also because of low maintenance requirements. The reasons for aluminium insufficient usage in civil engineering, in the context of primary structural members, is in most part the lack of education on its possibilities in relation to more popular materials (RC, steel and timber). Also, a legislative framework for such structures was established just recently, in 2013, when the Technical regulation for aluminium structures [42] came into effect. Another point is the lack of an extensive network of suppliers that is present when steel is in question. Moreover, there is a 
lack of fabricators that deal with aluminium, and consequently the lack of qualified welders and construction companies with such experience.

Aluminium alloys based kiosks can be seen all over Croatia, suited for various purposes, such as fast food, newspaper, bakery and multi-purpose stands - Fig. 18 .

Structural façade systems are implemented in residential, industrial, office and public buildings, almost every possible category of use. Fig. 19 shows an office building with a structural glass façade system built in Zagreb (Croatia), in 2008. It depicts a curtain wall application of a structural silicone façade on the entire building envelope.

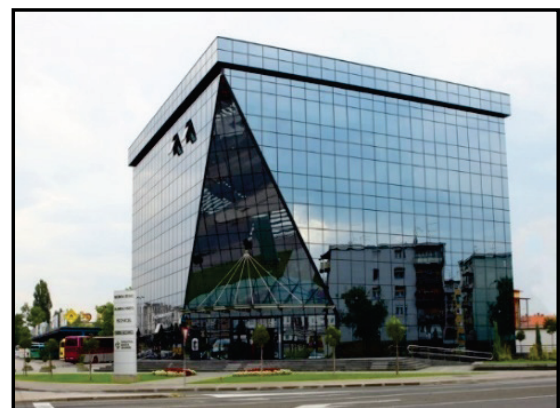

Figure 19 An office building with a structural silicone façade in Zagreb (Croatia) [43]

A special purpose application is depicted in Fig. 20. An aluminium-glass tramehorizontale system was used for the swimming pools building in Sv. Martin (Croatia). Aluminium is especially suitable for this high humidity area as it offers durability without special treatments.

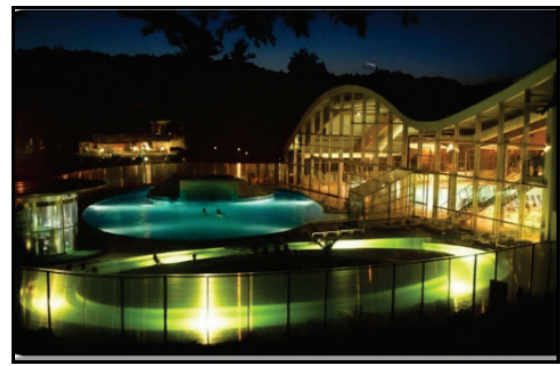

Figure 20 Tramehorizontale façade type for a swimming pool structure in Sv. Martin (Croatia) [43]

Representative industrial building with an implemented aluminium façade system in a bolted glass version is shown in Fig. 21. It was finished in 2007, in Kanafar (Croatia). The used glass was fitted in four layers, with an average piece area of $2 \mathrm{~m}^{2}$. Such a face enabled the architect's vision of an ever-changing, metamorphic shape of the building.

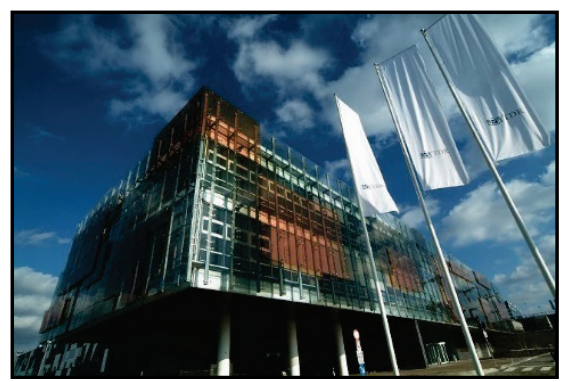

Figure 21 Industrial building in Kanafar (Croatia) with an implemented curtain wall bolted glass system [44]
Aluminium façade systems were utilized on the structure of a bus station in Osijek (Croatia) which was finished in 2011 (Figure 22). The tramehorizontale system emphasizes the building flow and adds to the vision of movement, which was to be established by the entire shape of the building.

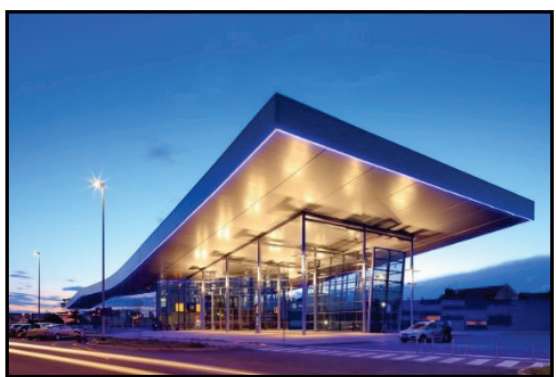

Figure 22 Bus station in Osijek (Croatia) with an aluminium-glass tramehorizontale façade type [43]

\section{Conclusions}

Aluminium alloys have been available as a structural material for a while now, but the degree of usage does not reflect the advantages possible to exploit by its application.

Requirements needed to correct current conditions are existent in the form of contemporary design manuals and production cost reduction enabled by a larger degree of recycling.

Evidence of usage possibilities is present in various structural applications, which embody advantages of aluminium in the form of low self-weight, corrosion resistance and cross section functionality. Such examples are shown in various engineering areas, with emphasized advantages of certain usage. These are also shown in a local context, of Croatia.

Although the usage of aluminium alloys is in rise, given examples show that certain areas are still undervalued. Current application expansion research indicates that there is still room for progress, beyond the field tested areas. It should be noted that the decision on using aluminium alloys should be weighed more than it currently is, especially in Croatia. Namely, given examples show lack of usage of aluminium as a primary structural element, but show promise through structural facades applications. The same trend can be said to be existent in the world, but with existent examples for guidance in other areas.

\section{References}

[1] Kissell, J. R.; Ferry, R. L. Aluminum structures: a guide to their specifications and design. John Wiley \& Sons, Inc., New York City, New York, USA, 2002.

[2] Ye, L.; Qian, P.; Feng, P. CFRP-aluminum alloy composite structures: a new type of composite structures in future. // Third International Conference on FRP Composites in Civil Engineering, Proceedings CFRP-aluminum alloy composite structures: a new type of composite structures in future / Miami, Florida, USA, 2006, pp. 709-712.

[3] Konstrukcije od Aluminijskih Legura. // Metalne konstrukcije - osnove proračuna i konstruisanja / Buđevac D; Marković Z; Bogavac D; Tošić D. Belgrade, Serbia: 
Faculty of Civil Engineering of the University in Belgrade, 1999.

[4] Efthymiou, E.; Cöcen, Ö. N.; Ermolli, S. R. Sustainable Aluminium Systems. // Sustainability. 2, 9 (2010), pp. 3100-3109. https://doi.org/10.3390/su2093100

[5] European Committee for Standardization (CEN). EN 19991-1, Eurocode 9: Design of aluminium structures - Part 1-1: General structural rules. CEN, Brussels, Belgium, 2007.

[6] European Committee for Standardization (CEN). EN 19991-2, Eurocode 9: Design of aluminium structures - Part 1-2: Structural fire design. CEN, Brussels, Belgium, 2007.

[7] European Committee for Standardization (CEN). EN 19991-3, Eurocode 9: Design of aluminium structures - Part 1-3: Structures susceptible to fatigue. CEN, Brussels, Belgium, 2007.

[8] European Committee for Standardization (CEN). EN 19991-4, Eurocode 9: Design of aluminium structures - Part 1-4: Cold-formed structural sheeting. CEN, Brussels, Belgium, 2007.

[9] European Committee for Standardization (CEN). EN 19991-5, Eurocode 9: Design of aluminium structures - Part 1-5: Shell structures. CEN, Brussels, Belgium, 2007.

[10] The Aluminum Association (AA). Aluminum Design Manual. AA, Washington, District of Columbia, USA, 2010

[11] Müller, U. Introduction to Structural Aluminum Design. Whittles Publishing, Dunbeath, Scotland, UK, 2011.

[12] Dokšanović, T.; Farkaš, M.; Njegovanović, N. Tržišna prihvatljivost građevinskog materijala s malim udjelom ugljika, Dio I: Materijali i mogućnosti smanjenja utjecaja na okoliš. // e-GFOS. 3, 5 (2012), pp. 1-20.

[13] Liu, G.; Müller, D. B. Addressing sustainability in the aluminum industry: a critical review of life cycle assessments. // Journal of Cleaner Production. 35, 0(2012), pp. 108-117. https://doi.org/10.1016/j.jclepro.2012.05.030

[14] European Aluminium Association (EAA). Activity Report 2011. EAA. 2012. URL: http://www.alueurope.eu/activityreport-2011/. (18.08.2012)

[15] Mazzolani, F. M. Structural Applications of Aluminium in Civil Engineering. // Structural engineering international. 16, 4(2006), pp. 280-285. https://doi.org/10.2749/101686606778995128

[16] Gitter, R. Design of Aluminium structures: Selection of Structural Alloys. // EUROCODES - Background and Applications, Proceedings Design of Aluminium structures: Selection of Structural Alloys / Brussels, Belgium, 2008.

[17] Dwight, J. Aluminium Design and Construction. Routledge, New York City, New York, USA, 1999. https://doi.org/10.4324/9780203028193

[18] Zhu, J.-H.; Young, B. Aluminum alloy tubular columnsPart I: Finite element modeling and test verification. // Thin-Walled Structures. 44, 9(2006), pp. 961-968. https://doi.org/10.1016/j.tws.2006.08.011

[19] European Aluminium Association (EAA). Aluminium use in Europe by country (2005-2008). EAA. 2010. URL: http://www.alueurope.eu/pdf/Use $\% 20$ by $\% 20$ country $\% 2020$ 08\%20Feb\%202010.pdf. (16.08.2012)

[20] European Aluminium Association (EAA). Aluminium use in Europe by country (2007-2010). EAA. 2014. URL: http://www.alueurope.eu/wp-content/uploads/2012/11/onlybrochure-sheets-Use-per-country-2010 withcolorsflags_final.pdf. (01.04.2015)

[21] Vojtech, D. Challenges for research and development of new aluminum alloys. // Metalurgija/Metallurgy. 49, 3(2010), pp. 181-185

[22] Coër, J.; Bernard, C.; Laurent, H.; Andrade-Campos, A.; Thuillier, S. The Effect of Temperature on Anisotropy Properties of an Aluminium Alloy. // Experimental Mechanics. 51, 7(2011), pp. 1185-1195. https://doi.org/10.1007/s11340-010-9415-6

[23] Maljaars, J.; Twilt, L.; Fellinger, J.; Snijder, H.; Soetens, F. Aluminium structures exposed to fire conditions-an overview. // HERON. 55, 2(2010), pp. 85-122.

[24] Dokšanović, T.; Markulak, D.; Džeba, I. State of the art review of the stability and welding of aluminium alloy elements. // Gradevinar. 66, 2(2014), pp. 115-125.

[25] Design of Connections. // Aluminium Structural Design / Soetens F; van Hove B. Udine, Italy: Springer-Verlag Wien New York, 2003. pp. 187-252.

[26] Spadaro, C.; Sunseri, C.; Dispenza, C. Laser surface treatments for adhesion improvement of aluminium alloys structural joints. // Radiation Physics and Chemistry. 76, 89(2007), pp. 1441-1446. https://doi.org/10.1016/j.radphyschem.2007.02.047

[27] European Aluminium Association (EAA). Aluminium in Building and Construction. EAA. 2010 http://www.alueurope.eu/pdf/Fact\%20Sheet_Building(1).pd f. $(16.08 .2012)$

[28] Mazzolani FM. Aluminium domes of the Enel plant in Civitavecchia, Italy. // HERON, 55, 3/4 (2010), pp. 171186.

[29] Mazzolani, F. M. New Challenges for Aluminium Structures: An Introduction. // Structural engineering international, 4(2006).

[30] Mazzolani, F. M. Contemporary aluminium structures: State-of-the art in application, research and codification. // Progress in Steel, Composite and Aluminium Structures, Proceedings Contemporary aluminium structures: State-ofthe art in application, research and codification / Rzeszow, Poland, 2006.

[31] Panico S. Aluminium shear panels for seismic protection numerical analysis and experimental tests. University of Naples Federico II, Naples, Italy, 2004.

[32] Mazzolani, F. M. Aluminium Structures in Refurbishment: Case of the Real Ferdinando Bridge on Garigliano River. // Structural engineering international, 16, 4(2006), pp. 352355. https://doi.org/10.2749/101686606778995182

[33] Mazzolani, F. M.; Mandara, A. Modern trends in the use of special metals for the improvement of historical and monumental structures. // Engineering Structures. 24, 7(2002), pp. 843-856. https://doi.org/10.1016/S0141-0296(02)00023-8

[34] De Matteis, G.; Formisano, A.; Panico, S.; Mazzolani, F. $\mathrm{M}$. Numerical and experimental analysis of pure aluminium shear panels with welded stiffeners. // Computers \& Structures. 86, 6(2008), pp. 545-555. https://doi.org/10.1016/j.compstruc.2007.05.027

[35] De Matteis, G.; Brando, G.; Mazzolani, F. M. Pure aluminium: An innovative material for structural applications in seismic engineering. // Construction and Building Materials. 26, 1(2012), pp. 677-686. https://doi.org/10.1016/j.conbuildmat.2011.06.071

[36] Aluminium Offshore. Helix Q5000. Aluminium Offshore. 2015. http://www.aluminium-offshore.com/news/helixq5000/. (23.09.2015)

[37] Walbridge S; de la Chevrotière A. Opportunities for the use of Aluminum in Vehicular Bridge Construction. MAADI Group. 2012. http://www.maadigroup.com/wp-content/ uploads/2013/02/Aluminum-Bridge-Report.pdf. (23.09.2015)

[38] Soetens, F.; Mennink, J. Aluminium building and civil engineering structures. // ISCAS 4th International Conference on Steel and Aluminum Structures, Proceedings Aluminium building and civil engineering structures / Espoo, Finland, 1999, pp. 487-494. https://doi.org/10.1016/B978-008043014-0/50159-1

[39] Kaufman, J. G. Introduction to aluminum alloys and tempers. ASM International, Russell Township, Ohio, USA, 2000. 
[40] Flanagan Lawrence. Hammersmiths Grove 10. Flanagan Lawrence 2015. http://flanaganlawrence.com/project/10hammersmith-grove-w4/\#/project. (03.10.2015)

[41] Lother, K. Kinked façades for high-rise Towers in Hamburg. // Intelligent glass solutions (IGS). 4, (2011), pp. 64-67.

[42] Tehnički propis za aluminijske konstrukcije. Narodne Novine br $80 / 2013$.

[43] FEAL. Reference. FEAL d.o.o. 2015. http://feal.hr/ reference $(02.10 .2015)$

[44] Adris grupa. Nove tvornice u Kanafaru. Adris grupa. 2007. http://www.adris.hr/biti-bolji-biti-drugaciji/nove-tvorniceu-kanfanaru/ (03.10.2015)

\section{Authors' addresses}

Tihomir Dokšanović, mag. ing. aedif. Faculty of Civil Engineering Osijek, University of Osijek Drinska 16a, HR-31000, Osijek, Croatia tdoksanovic@gfos.hr

Ivica Džeba, prof. dr. sc.

Faculty of Civil Engineering, University of Zagreb

Fra Antuna Kačića Miošića, HR-10000, Zagreb, Croatia ivci@grad.hr

Damir Markulak, prof. dr. sc.

Faculty of Civil Engineering Osijek, University of Osijek Drinska 16a, HR-31000, Osijek, Croatia

markulak@gfos.hr 